\title{
Rotational atherectomy in high-surgical-risk patient with unstable coronary heart disease
}

Aterektomia rotacyjna u osoby z niestabilną chorobą wieńcową i dużym ryzykiem rewaskularyzacji chirurgicznej

\author{
Sławomir Dobrzycki, Artur Dubicki, Paweł Kralisz, Konrad Nowak \\ Department of Interventional Cardiology with ICU and Catheterization Laboratory, University Clinical Hospital, Bialystok, Poland
}

Post Kardiol Interw 2011; 7, 2 (24): 185-187

DOI: $10.5114 /$ pwki.2011.23173

\begin{abstract}
A case of an 85-year-old patient with unstable coronary heart disease treated with complex percutaneous coronary intervention of the left main coronary artery, left anterior descending artery and circumflex artery with rotablation and implantation of three drugeluting stents (Rota-DES technique) is presented.
\end{abstract}

Key words: rotational atherectomy, drug-eluting stent, acute coronary syndrome

\section{Streszczenie}

85-letni mężczyzna z niestabilną chorobą wieńcową, leczony kompleksową angioplastyką pnia, gałęzi przedniej zstepującej i okalającej lewej tętnicy wieńcowej z zastosowaniem rotablacji i implantacją trzech stentów uwalniających lek antyproliferacyjny (tzw. technika Rota-DES).

Słowa kluczowe: aterektomia rotacyjna, stent uwalniający lek, ostry zespół wieńcowy

\section{Introduction}

Percutaneous coronary interventions $(\mathrm{PCl})$ are an established method of treatment in patients with unstable coronary heart disease or myocardial infarction. In some situations, especially in cases of calcified coronary artery stenosis, a classic PCl may be unsuccessful. A tool which can be very helpful in these situations is rotational atherectomy. This technique allows one to perform a successful modification of atherosclerotic plaque and preparation of the lesion for the optimal stent implantation which determines a successful procedure.

We present a case of an 85-year-old patient with unstable coronary heart disease treated with complex percutaneous coronary intervention of the left main coronary artery (LMCA), left anterior descending artery (LAD) and circumflex artery (Cx) with the use of rotablation and implantation of three drug-eluting stents.

\section{Case report}

An 85-year old man with a long lasting history of coronary heart disease, permanent atrial fibrillation, chronic kidney disease and obesity was transferred from the regional hospital to the Department of Interventional Cardiology due to aggravation of angina and decompensation of chronic heart failure. A year before he experienced an anterior non-ST-elevation myocardial infarction. Coronary angiography performed at that time showed the presence of multivessel coronary artery disease with significant left main coronary artery stenosis, but the patient refused surgical treatment. Chest pains worsened three weeks before the currently described hospitalization and required sublingual administration of nitroglycerine several times a day, including the night hours. On admission the patient was in a moderate general condition. He complained of chest discomfort. Physical examination 


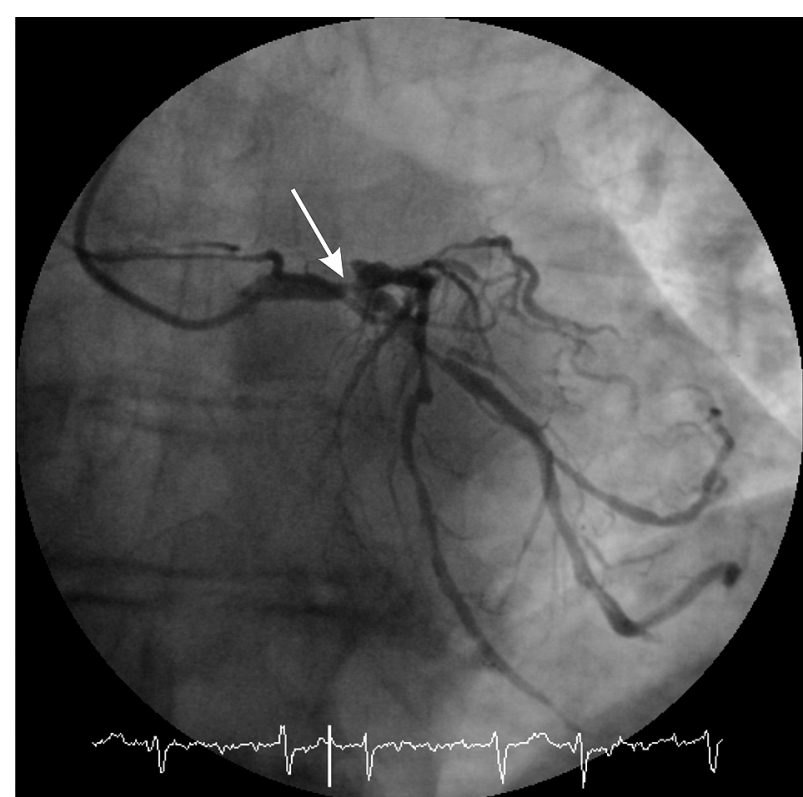

Fig. 1. Angiogram of the left coronary artery (arrow - left main coronary artery stenosis)

Ryc. 1. Koronarografia lewej tętnicy wieńcowej (strzatka-zwężenie w pniu lewej tętnicy wieńcowej)

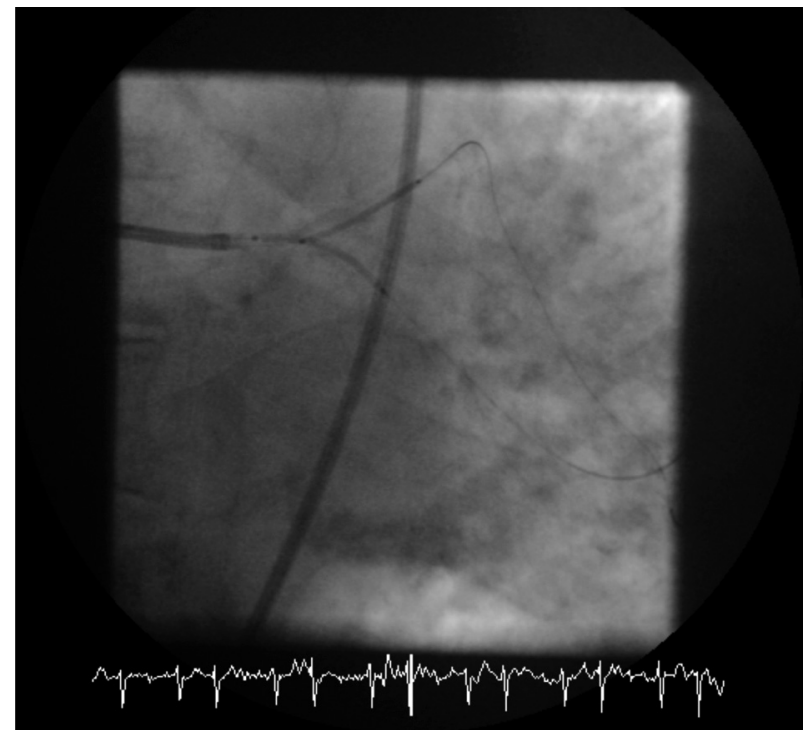

Fig. 3. Implantation of two everolimus-eluting stents: "small protrusion" technique

Ryc. 3. Implantacja dwóch stentów uwalniających ewerolimus; technika „small protrusion”

revealed loud systolic murmur over the heart with "punctum maximum" over the aortic valve, peripheral oedema, completely irregular heart rhythm and blood pressure of 100/70 mmHg. Electrocardiogram demonstrated atrial fibrillation with mean heart rate of $100 \mathrm{bpm}$, left anterior hemiblock of the left His bundle branch,

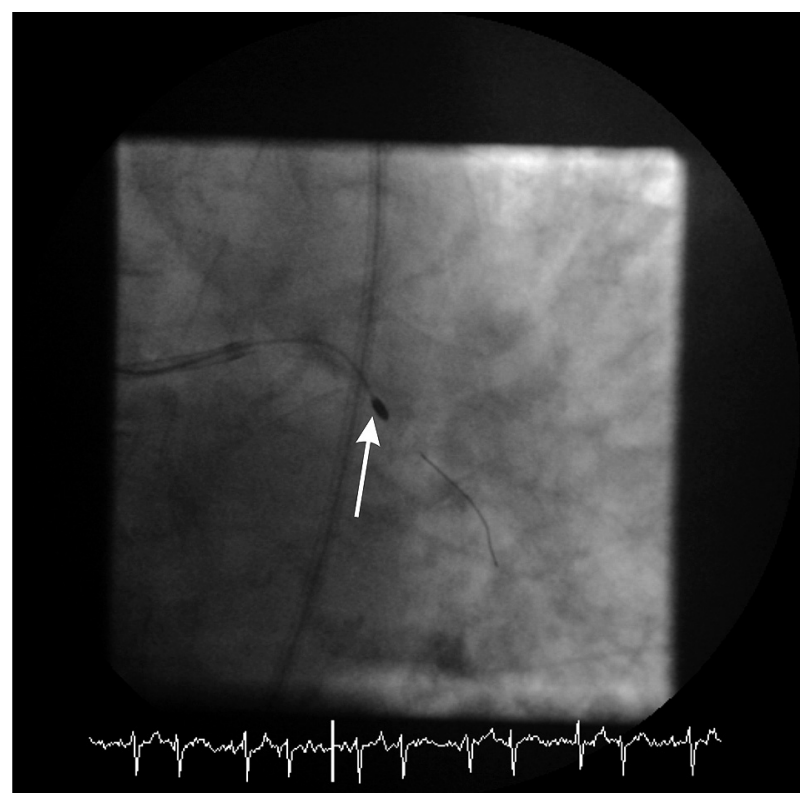

Fig. 2. Rotational atherectomy of the left main coronary artery and circumflex artery (arrow - rotablator drill)

Ryc. 2. Atrektomia rotacyjna w pniu lewej tętnicy wieńcowej i gatęzi okalającej (strzatka - wiertło rotablatora)

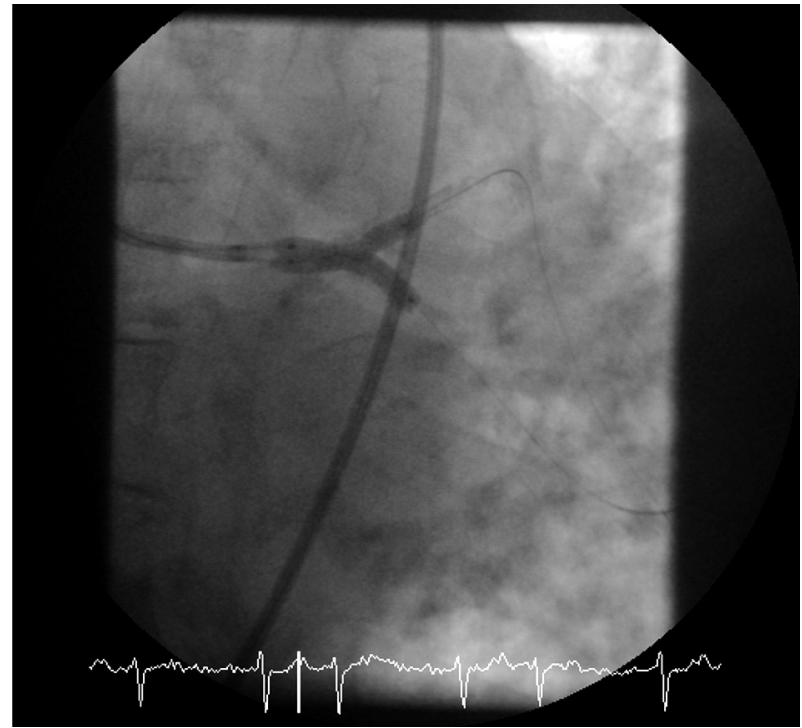

Fig. 4. Procedure optimization with the "kissing balloons" technique

Ryc. 4. Optymalizacja zabiegu metoda „kissing balloons"

ST-segment depression in precordial leads and elevation in the aVR lead. Echocardiography showed an enlarged left atrium, mild left ventricular hypertrophy, moderate aortic valve stenosis and mild regional hypokinesia with ejection fraction of $58 \%$. Laboratory tests did not show significant abnormalities. Coronary angiography performed via the 
right transradial access demonstrated critical stenosis of the distal left main coronary artery segment (fig. 1) including the ostium of the left anterior descending artery and circumflex artery along with significant stenosis in the proximal part of the circumflex artery and distal segment of the right coronary artery. After surgical consultation (taking into account the high risk of the procedure Euroscore $-25.84 \%$ and Syntax Score - 32) the patient was qualified for complex $\mathrm{PCl}$ of the LMCA, LAD and Cx with the use of rotational atherectomy. After engagement of the LMCA ostium with a $4.07 \mathrm{~F} \mathrm{EBU}$ guiding catheter (Launcher Medtronic) 7000 IU of heparin was administered by the intracoronary route. Subsequently a 0.014 " guidewire for atherectomy (Rota Wire Extra Support, Boston Scientific) was introduced to the distal part of the LAD. As the next step rotablation of the LMCA and proximal LAD were performed using a $1.75 \mathrm{~mm}$ drill (Rota Burr, Boston Scientific). Subsequently the guide-wire was removed from the LAD to put in the Cx and the same drill was used for LMCA/Cx rotablation (fig. 2). This was followed by predilation of the LMCA/LAD and LMCA/CX with a $3.5 / 20 \mathrm{~mm}$ balloon catheter under maximal pressure of $10 \mathrm{~atm}$ (Sprinter, Medtronic). Subsequently two everolimus-eluting stents were implanted using the "small protrusion" technique $-3.0 / 24 \mathrm{~mm}$ under 16 atmospheres into the LAD (Promus Element, Boston Scientific) and 4.0/20 mm under $16 \mathrm{~atm}$ into the LMCA/CX (Promus Element, Boston Scientific) (fig. 3). This was followed by implantation of an overlapping stent into the stenosed proximal part of the $\mathrm{Cx}-3.5 / 12 \mathrm{~mm}$ under $18 \mathrm{~atm}$ (Promus Element, Boston Scientific). The procedure was optimized using the "kissing balloons" technique (figs. 4, 5). The arterial access was closed using a $8 \mathrm{~F}$ vascular occluder (Angio Seal, St. Jude Medical). The patient did not complain of angina after mobilization. The dose of the $\beta$-blocker was increased, spironolactone was discontinued due to signs of gynecomastia and an oral anticoagulant was not administered due to a history of epistaxis. The patient was discharged home after 5 days of hospitalization in a good general condition. On discharge he was instructed to take clopidogrel ( $1 \times 75 \mathrm{mg}$ for 12 months minimum), aspirin $(1 \times 75 \mathrm{mg})$, bisoprolol $(1 \times 10 \mathrm{mg})$, ramipril $(1 \times 5 \mathrm{mg})$, furosemide $(1 \times 40 \mathrm{mg})$, simvastatin $(1 \times 40 \mathrm{mg}$ in the evening) and pantoprazole $(1 \times 20 \mathrm{mg})$. The patient remains in good clinical condition under ambulatory follow-up and refuses a control coronary angiography.

\section{Discussion}

Dynamic development of the $\mathrm{PCl}$ techniques and growing experience of the interventional cardiologists lead to higher efficacy and safety of the procedures. Percutaneous coronary interventions remain the main revascularization strategy in patients with acute coronary syndromes. Surgical revascularization in patients with acute coronary syndromes should be taken into account in cases of very unfavourable anatomy of the lesions

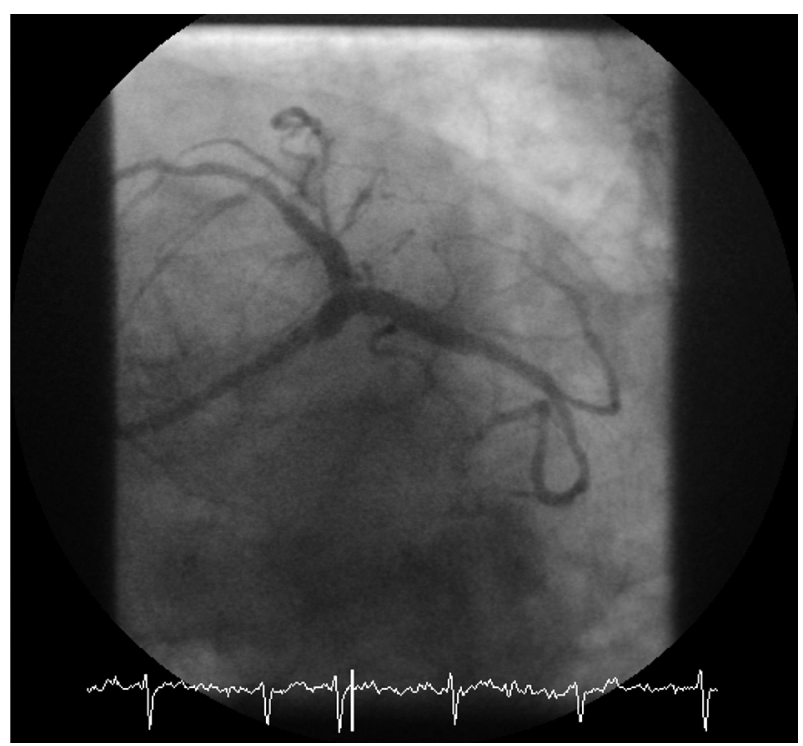

Fig. 5. Final effect of the procedure

Ryc. 5. Ostateczny efekt zabiegu

responsible for the event in patients with multivessel coronary artery disease including LMCA stenosis [1, 2].

The presented patient with unstable coronary heart disease was qualified for early invasive treatment. Coronary angiography performed via transradial access showed the presence of multivessel coronary artery disease with significant distal LMCA stenosis. After surgical consultation (taking into account the very high risk of the surgical procedure) and interventional cardiologist consultation regarding the feasibility of $\mathrm{PCl}$, it was decided to perform angioplasty with the use of rotational atherectomy and implantation of antiproliferative drug-eluting stents (the so-called Rota DES technique) [3, 4]. The use of a rotablator successfully modified the calcified plaque and allowed us to continue and successfully finish the procedure [5].

\section{References}

1. Bassand JP, Hamm CW, Ardissino D, et al. Guidelines for the diagnosis and treatment of non-ST-segment elevation acute coronary syndromes. Task Force for Diagnosis and Treatment of Non-ST-Segment Elevation Acute Coronary Syndromes of European Society of Cardiology. Eur Heart J 2007; 28: 1598-1660.

2. Hochholzer W, Buettner HJ, Trenk D, et al. Percutaneous coronary intervention versus coronary artery bypass grafting as primary revascularization in patients with acute coronary syndrome. Am J Cardiol 2008; 102: 173-179.

3. Furuichi S, Sangiorgi GM, Godino C, et al. Rotational atherectomy followed by drug-eluting stent implantation in calcified coronary lesions. Eurolntervention 2009; 5: 370-374.

4. Khattab AA, Richardt G. Rotational atherectomy followed by drugeluting stent implantation (Rota-DES): a rational approach for complex calcified coronary lesions. Minerva Cardioangiol 2008; 56: 107-115.

5. Moses JW, Carlier S, Moussa I. Lesion preparation prior to stenting. Rev Cardiovasc Med 2004; 5 Suppl 2: 16-21. 